Article

\title{
Analysis of Environmental Awareness, Emotions and Level of Self-Efficacy of Teachers in Training within the Framework of Waste for the Achievement of Sustainable Development
}

\author{
Guadalupe Martínez-Borreguero * ${ }^{\circledR}$, Jesús Maestre-Jiménez, Milagros Mateos-Núñez and \\ Francisco Luis Naranjo-Correa \\ Department of Science Teaching, University of Extremadura, 06006 Badajoz, Spain; \\ jemaestre@alumnos.unex.es (J.M.-J.); milagrosmateos@unex.es (M.M.-N.); naranjo@unex.es (F.L.N.-C.) \\ * Correspondence: mmarbor@unex.es; Tel.: +34-924-289-300
}

Received: 2 March 2020; Accepted: 22 March 2020; Published: 24 March 2020

\begin{abstract}
The United Nations General Assembly has pointed out that education is an essential tool for properly instructing society to achieve sustainable development, in terms of values, skills, knowledge or abilities. Within this framework, this research focuses on environmental attitude and awareness as an influential element in the teaching and learning processes. The main objective of the study was to diagnose and evaluate emotional, teaching self-efficacy and environmental awareness variables of teachers in primary and secondary education training within the framework of waste. The sample was made up of 160 teachers in training. As a measurement instrument, a questionnaire was designed, developed and validated consisting of three different parts to measure the variables under investigation. The descriptive and inferential statistical analysis of the data shows attitudinal, emotional and self-efficacy differences according to the categories examined, revealing the need to promote an improvement in the attitude towards certain environmental actions in future teachers. The results suggest that education has a relevant role in sustainability, and its importance and inclusion in the curricula of the different educational stages should be recognized.
\end{abstract}

Keywords: sustainable development; teacher in training; primary education; secondary education; waste; awareness; emotions; teacher self-efficacy

\section{Introduction}

In recent years it has been agreed that there is an urgent need to adopt a more sustainable approach to our habits and lifestyles because of our impact on the environment. This is why the UN General Assembly established the 2030 Agenda for Sustainable Development, an action plan for people and the planet, composed of 17 Sustainable Development Goals covering economic, social and environmental areas and involving a common and universal commitment [1]. In addition, population growth, the booming economy, rapid urbanization and rising standards of living in communities have significantly accelerated the generation of solid waste around the world [2]. According to some authors [3], negative attitudes towards the environment and a low level of environmental awareness among the population are variables that can have a great social impact, highlighting the need for education for sustainable development. In addition, several studies point out that techno-scientific development is the key to solving social and environmental problems. In other words, the occidental system has deposited an exaggerated confidence in science and technology to know how to respond to the depletion of resources and pollution processes [4], forgetting that one of the main environmental problems has been the growing production of goods and hyper-consumption [5]. 
Excessive consumption and a throwaway culture have generated excessively high waste production values per inhabitant $[2,6,7]$. Consequently, the increase in waste volumes, the scarcity of landfills and the adverse long-term environmental, economic and social impacts of waste generation mean that sustainable management is essential to protect public health and natural ecosystems [8]. According to some research [8], much of the population has little idea about the origin and destination of goods, the destructive impact of pollution on human health, and the importance of maintaining productive and biologically diverse ecosystems [8]. The belief that natural and physical resources are free and inexhaustible and that the environment can assimilate all our pollution and waste has led to an unsustainable use of renewable resources and an excessive use of non-renewable resources [9]. This belief also leads to the overuse of land, air and water bodies as reservoirs of pollution and waste. Thus, since human action is at the heart of environmental issues, sustainable development ultimately depends on changing human behavior [10]. In the last decade, a new step has been taken in terms of educational goals, as it is considered that, while they should continue to be oriented towards sustainable development, they should focus on individuals and the community rather than on the environment [11]. In this respect, environmental interventions should be assessed globally from the political, economic, social and ethical points of view. However, promoting public participation and individual action remains a challenge for governments, organizations and institutions around the world $[1,12,13]$. Many researchers and government institutions are working intensively on the development of regulations that promote the prevention of waste generation and, if this is not possible, encourage its reduction, reuse, recycling, energy recovery, treatment and final disposal, as a last resort [14-17]. Proof of this are the numerous meetings of international interest, the objective of which has been to promote respect for the environment [18,19]. Thus, for example, in September 2015 the United Nations Assembly adopted the Sustainable Development Goals (SDGs) as an international agenda that will guide development policies over the next 15 years, so that the countries of the world continue their efforts to achieve sustainability [20]. In addition, the Sustainable Development Goals decided upon by the United Nations include an objective (SGD 4 "Quality Education") focused on the acquisition by students of the knowledge and skills needed to promote sustainable development [20]. Furthermore, in Europe, with different norms, elements that could be harmful to the planet have been regulated [21-25] and in Spain Law 22/11 on waste and contaminated soil has been implemented [26] in order to manage certain human behaviors.

The solutions to the global crisis that have found the greatest consensus recognize that environmental problems are not only problems of development, but basically problems of knowledge and education that go beyond learning about the environment, and that also have to do with the way in which environmental problems are understood and addressed [27]. We citizens urgently need to acquire scientific-environmental knowledge and ecological behavior that allows us to develop without growing beyond our limits and to develop a new intellectual culture of consumption and technology [28]. In this regard, to increase people's awareness of these issues, numerous international resolutions and recommendations emphasize the need to incorporate education for sustainability into the curriculum at all levels of education [29]. Thus, the introduction of the sustainability paradigm into the discourses and practices of the educational world is causing a structural shift that forces a review of educational culture [11]. In addition, in 2005 the United Nations declared the Decade of Education for Sustainable Development, a period aimed at incorporating education for sustainable development into education systems [30,31]. Knowledge of the environment, the development of attitudes and behavior on its behalf, and the skills needed to be able to act on it, are recognized as priority objectives of education [32]. Based on this, some of the sustainable elements of special interest have been introduced in the objectives and contents of the education curricula of the different countries [33-35]. However, it is also necessary to redefine the new educational scenarios, their times and rhythms and the role of teachers and all actors involved in school practice. In this way, it is intended that students be able to make a critical analysis of the socio-economic framework that has determined the current unsustainable trends and to prepare a responsible and capable citizenship for sustainable decision-making in a global 
and complex world [11]. Likewise, this curricular integration of environmental concepts not only promotes an improvement in student behavior to alleviate current environmental problems but also an improvement in the cognitive domain from a STSE (Science, Technology, Society and Environment) perspective [36-38]. Additionally, it is necessary to consider that primary school teachers are the most influential in the education of children and adolescents to be tomorrow's leaders in environmental protection. For this reason, in order to effectively integrate education for sustainable development into the students of future generations, teachers in training at the primary and secondary levels should have a good knowledge of the environment to ensure effective teaching and demonstrate environmentally friendly behavior and attitudes [39].

In this line of research, referring to attitudes that predict environmental behavior, it is worth highlighting some of the studies carried out to try to explain, describe and predict the performance of responsible behavior with the environment within the field of education. For example, some authors [39] stress that the positive attitudes towards the environment shown by secondary school teachers do not fully translate into environmentally friendly behavior. In this sense, other research [40-42] agrees that people only behave in an environmentally responsible manner when they are sufficiently informed about environmental issues, are motivated to do so and, furthermore, are capable of generating qualitative changes, are convinced of the effectiveness of their actions and that these will not generate significant difficulties. On the contrary, other works [43] maintain that there is a positive relationship between pro-environmental attitudes and the performance of pro-environmental behaviors. The results obtained in other studies [44] show that thinking and behaving pro-environmentally not only benefits the environment, but also leads to greater emotional well-being. On the other hand, some research [45] has revealed that it is mainly female teachers who show significantly higher levels of environmental awareness compared to their male counterparts. Other studies $[46,47]$ indicate that in order to assess an attitude, it is necessary to consider inherent factors such as knowledge, disposition and behavior. It has been shown that knowledge alone does not produce automatic changes in behavior. However, what does exist is a cyclical relationship of reinforcement between knowledge about the environment and environmental attitudes, and that the latter mark certain tendencies of adequate behavior towards the environment $[48,49]$. For example, knowledge of recycling programs and sorting patterns has been associated with increased recycling behavior [50].

Other authors studied students' knowledge of municipal solid waste and their attitudes towards consumption [51,52]. The results revealed the need to improve both knowledge [52] and attitudes in this field [51]. In this regard, some research [53] indicates that adequate environmental literacy of students will be achieved when teachers themselves have good knowledge of the environment. On the other hand, research by other authors [31] shows that a large number of textbooks suggest the application of new technologies as the only solution to problems such as waste management, and that there is a lack of efforts to prevent or reduce these problems or to promote the reduction of our current excessive level of consumption. Specifically, despite the campaigns carried out by various institutions, values and knowledge related to environmental problems are not progressing [52]. Various studies indicate that this may be due to misinformation about environmental problems that is disseminated through the media, social networks, the Internet, newspapers and magazines [54]. Other studies suggest that slow processes and the lack of involvement of teachers in promoting sustainability, the lack of recognition of these activities in the university curriculum and the lack of institutional support are possible causes $[55,56]$. For this reason, it is necessary to carry out from the educational field different proposals focused on this subject aimed, for example, at detecting deficiencies both from the point of view of knowledge and of the attitudes of students and teachers in training. It is expected that future primary and secondary school teachers will be responsible for teaching the different sustainable and environmental concepts, constituting the pillars related to knowledge and attitudes of the teaching and learning process of the key concepts for sustainable development. However, universities can play a crucial role in developing sustainable development goals and promoting sustainability at higher education levels [29]. 
Considering the aforementioned scientific literature, one of the purposes of this work was to instill in future teachers the Sustainable Development Goals proposed by the United Nations [1,20], the one most closely related to the study being SDG 12 "Responsible Consumption and Production". This objective seeks to promote the efficient use of resources and energy, the construction of environmentally friendly infrastructure and to raise consumer awareness through education on sustainable lifestyles. This study also complements previous research addressing the concept of waste in the educational field. Specifically, this research is based on previous studies carried out by [34] in which reference to the concept of waste was analyzed in the regulations unifying Compulsory Secondary Education (CSE) and the Baccalaureate in Spain. That study concluded that the regulations governing secondary education in Spain should deal more deeply with the concept of waste since the limited role played by this concept in the legislation is transferred to our society and materializes in the lack of adequate waste management. In this line, another study [35] should also be mentioned, which analyses the references included in the secondary education curriculum on the concept of energy from a sustainable perspective and concludes that both national and regional legislation consider the teaching of this concept to be relevant from the point of view of sustainable development and that there is a clear commitment in this field for the training of Spanish citizens. Lastly, this study is also supported by other research [52] which analyses the level of knowledge that future teachers have about waste, highlighting the importance of initiating environmental education and nature conservation programs to promote pro-environmental knowledge and attitudes about waste. In line with this background, we understand the environmental attitude and awareness as an influential element in the teaching and learning processes. Therefore, in the research presented here, we analyze the environmental awareness of teachers in training for the achievement of sustainable development. Specifically, we focus on the waste framework, where we additionally analyze the emotions and level of self-efficacy presented by future primary and secondary school teachers in order to impart these contents to their future students, relating them to the level of knowledge they present in this field based on the analysis of the current education curriculum.

\section{Materials and Methods}

The design of the research carried out was of an exploratory descriptive type, with mixed qualitative and quantitative analysis of the data obtained, in order to achieve the proposed objectives and to respond to the study's hypotheses.

\subsection{Objectives}

The research has two general objectives:

- The general objective 1 (GO1) was to diagnose and assess the attitudes and level of environmental awareness on waste in primary and secondary school teachers in training.

- The second general objective 2 (GO2) was to analyze emotional and self-efficacy variables of future teachers in relation to waste and its management.

- Based on these general objectives, the following specific objectives have been formulated:

- Specific objective 1 (SO1): To develop a survey to measure the level of environmental awareness in relation to the concept of waste based on a system of categories obtained in the study of the analysis of the secondary education curriculum [34].

- Specific objective 2 (SO2): To analyze and compare the attitude of future primary and secondary education teachers on the concept of waste in each of the established categories.

- Specific objective 3 (SO3): To analyze the level of knowledge of future primary and secondary education teachers about the concept of waste in each of the established categories.

- Specific objective 4 (SO4): To analyze the emotions and the level of teaching self-efficacy of future primary and secondary education teachers on the concept of waste in each of the established categories. 
- Specific objective 5 (SO5): To analyze and compare the influence of the gender variable on the attitudes and environmental awareness of future primary and secondary school teachers.

\subsection{Study Hypothesis}

Based on the research objectives, the following hypotheses have been formulated:

- Hypothesis 1 (H1): Teachers in training in the sample have the right attitude to develop their future teaching work in the field of waste, with statistically significant differences being found depending on the degree taken.

- Hypothesis 2 (H2): Future teachers in the sample have a low level of knowledge about the concept of waste in each of the established categories, with statistically significant differences being found depending on the degree taken.

- Hypothesis $3(\mathrm{H} 3)$ : Women show greater environmental awareness than men regarding the concept of waste in the sample.

- Hypothesis $4(\mathrm{H} 4)$ : Teaching the concept of waste mainly generates positive emotions and attitudes in future teachers in the sample.

- Hypothesis 5 (H5): There are statistically significant differences in the level of teaching self-efficacy of teachers in training in the sample depending on the content to be taught.

\subsection{Sample}

The participating sample in this study was selected through non-probability sampling for convenience, due to the ease of access. Specifically, it was made up of 160 teachers in training. This group was made up of students from the degree of primary education (future primary education teachers) and students from the master's degree in teacher training in secondary education in different specialties: Physics/chemistry and biology/geology (future secondary education teachers). The choice of this sample was motivated by the need, from a point of view of education in the framework of sustainable development, to analyze the attitude of future teachers to explain concepts related to waste. It is considered that this group will have in their hands the scientific training of future generations and, therefore, their contribution to the achievement of the Sustainable Development Goals proposed by the United Nations [20]. Table 1 shows a descriptive analysis of the selected sample. The absolute frequency and percentage of the variables gender, age and degree are indicated; $73.8 \%$ of the respondents are women and that most of them are between 20 and 29 years old. The degree with the greatest frequency is that of primary education.

Table 1. Descriptive analysis of the sample.

\begin{tabular}{cccc}
\hline & Variable & Frequency & Percentage \\
\hline \multirow{2}{*}{ Genre } & Male & 42 & 26.3 \\
& Female & 118 & 73.8 \\
\hline \multirow{2}{*}{ Age } & $20-29$ & 146 & 91.25 \\
& $30-35$ & 10 & 6.25 \\
& $>35$ & 4 & 2.5 \\
\hline \multirow{2}{*}{ Degree } & Master's degree in Teacher & 42 & 26.3 \\
& Training in Secondary Education & 118 & 73.8 \\
& Degree in Primary Education & & \\
\hline
\end{tabular}

\subsection{Design of the Measuring Instrument}

As a measuring instrument, a questionnaire was designed and developed in two different parts to measure the variables under study. In the first part, the aim is to assess the participants' environmental awareness variable in order to achieve sustainable development in the context of waste. To measure this variable, we have relied on previous studies [5,34,35,52]. On the other hand, with respect to the 
affective domain, the second part of the questionnaire aims to measure emotional variables, referring both to positive and negative emotions experienced by future primary and secondary school teachers when teaching curricular content referring to waste within the framework of sustainable development. Likewise, it is intended to measure the level of teaching self-efficacy expressed by future teachers in view of the teaching procedure of the contents selected in the study. For the design of this part of the questionnaire and the selection of the variables (measurement of emotions and level of teaching self-efficacy), we have relied on questionnaires designed in previous research $[57,58]$.

The various parts of the questionnaire prepared are detailed below. The first part of the questionnaire included a survey of 30 items based on a 5-point Likert scale, where the value 0 indicates "Completely Disagree", 1 "Strongly Disagree", 2 "Somewhat Disagree", 3 "Somewhat Agree", 4 "Strongly Agree" and the value 5 "Completely Agree". The survey was developed based on the results obtained in the studies of the analysis of the concept of waste and energy in the current curriculum $[34,35]$ and the study of [52] in which the level of knowledge presented by future teachers about waste is analyzed. These studies made it possible to categorize the references found to this concept in the legislation and served as a basis for the formulation of the items based on the category system established in the educational curriculum. Specifically, the categories established were the following:

- Category I Waste and Society (WS): In this category we include those questions about environmental or social problems in which waste is referenced.

- Category II Normative and Economy (NE): This category includes references related to waste regulations as well as those affecting economic activities.

- Category III Awareness and Ethics (AE): This category includes references to the importance of an ethical and awareness-raising perspective on waste issues.

- Category IV Technological Development (TD): This category includes references to the contribution of technological development to the achievement of proper waste-related problem solving.

- Category V Typology (T): This category includes references related to the typology and origin of waste.

As mentioned above, these categories have been selected on the basis of the legal regulations in relation to the level of educational importance of the concept of waste for sustainable development, and of the social (in the categories Waste and Society and Awareness), economic (category Normative and Economy) and environmental factors (categories Technological Development and Typology). In each category, six items have been formulated that encompass the most important knowledge reflected in the regulations governing the education curriculum [59]. In selecting and organizing the items to assess participants' attitudes, the design of attitude surveys from previous studies [60] was considered, suggesting that the item statements should be presented in the first person and should reflect personal opinion or willingness to act. In addition, questions should be formulated in direct language that, whenever possible, should be matched with expressions characteristic of students at the level being explored [60]. The recommendation suggested by other authors [47] to have a sample five times larger than the number of items was also considered.

Based on the above, the items were written in first person to analyze the degrees of environmental awareness and acceptance, both positive and negative in the different established categories. Each item can express a negative or positive attitude. Specifically, items 1, 2, 6, 7, 8, 10, 15, 17, 19, 20, 21, 25, 27 and 29, present negative attitudes, so that their expected value should be close to 0 . On the other hand, items $3,4,5,9,11,12,13,14,16,18,22,23,24,26,28,30$ present positive attitudes, and their expected value should be close to 5 .

Category I "Waste and Society" is made up of items 5, 6, 7, 13, 19 and 25 and refers to the influence of waste on our daily lives. Secondly, the items referred to in Category II "Normative and Economy" mention aspects such as sustainable production and consumption and are specifically 2, 10, 11, 20, 26 and 27. The items that make up Category III "Awareness and Ethics" are based on actions to reduce, recover waste and concepts related to the care of ecosystems. These items are 1, 3, 12, 21, 22 and 28. 
The items of category IV "Technological Development" relate the concept of waste to quality of life or energy enhancement and are 4, 9, 14, 18, 23 and 29. Finally, category V "Typology" includes the remaining six items of the survey, items $8,15,16,17,24$ and 30, and generally focuses on recycling and the elements that could be recovered according to the type of waste they generate.

As an example, Table 2 shows one item from each category. The entire list of items can be seen in the results section.

Table 2. Examples of items formulated in each category.

\begin{tabular}{cc}
\hline Category & Example of Formulated Item \\
\hline Category I (Waste and Society) & I06: "I am sure that media campaigns don't \\
help recycling". & $\begin{array}{c}\text { I20: "I believe that the production of nuclear waste is } \\
\text { not related to a country's energy consumption". } \\
\text { Category II (Normative and Economy) }\end{array}$ \\
I22: "Maybe one of the biggest environmental \\
problems we have is the generation of nuclear waste". \\
I04: “I am sure that some waste can be used to \\
improve people's quality of life". \\
Category IV (Technological Development) \\
I18: "I am sure that actions to reduce waste \\
Category V (Typology) & $\begin{array}{c}\text { production are aimed at reducing, reusing, recycling } \\
\text { and recovering waste". }\end{array}$ \\
\hline
\end{tabular}

The second part of the questionnaire consisted of evaluating, by means of a Likert scale, the degree of manifestation of different emotions when dealing with the explanation of waste contents. The emotions selected were enthusiasm, fear, confidence, concern, tranquility, stress, fun, anxiety, despair, satisfaction and joy. These emotions are classified as positive or negative in the literature in the different categorizations $[57,61,62]$. The participating teachers had to assess on a Likert scale the frequency with which they expressed these emotions when the contents under study were taught. In addition, this section also assessed the level of teaching self-efficacy $[63,64]$ expressed by the participants in the process of teaching the selected content on waste.

\subsection{Validation of the Evaluation Instrument: Calibration Indexes}

For the validation of the 30 statements survey, different calibration indexes were calculated, specifically the homogeneity index or item-total correlation tests and Cronbach's alpha [65]. With respect to the homogeneity index and item-total correlation tests, $73.3 \%$ of the test presented items with a homogeneity index within the standard parameters. The remaining $26.7 \%$ correspond to the categories of Waste and Society (CAT I) and Awareness and Ethics (CAT III). These results are in line with previous studies $[52,66]$ that showed that future teachers in training have low knowledge in the categories of Normative and Economy (CAT II), Technological Development (CAT IV) and Typology (CAT V). However, the categories where they show the most knowledge are Waste and Society (CAT I) and Awareness and Ethics (CAT III). To measure the reliability of the questionnaire, Cronbach's Alpha was calculated, obtaining a value of 0.62 . This result is within the value of acceptable reliability, which is in the range of $0.6-0.8$ according to different studies [67].

\section{Results}

The results obtained allowed us to learn about various aspects of the current attitudes of future teachers in relation to waste and its impact on society. A descriptive and inferential analysis of the study variables is presented to contrast the different research hypotheses. Firstly, the descriptive values obtained in the items of the questionnaire are presented and then an analysis by categories will be provided. Finally, the inferential values obtained for the variables considered are shown. 


\subsection{Results Referring to the Variables Environmental Awareness of the Teachers in Training}

This section shows the results referring to the level of environmental awareness shown by future teachers in the field of waste and presents a comparison between the attitudes that reveal the environmental awareness of primary school teachers versus secondary school teachers.

Table 3 shows the statements of the items that make up the questionnaire designed, the mean, the standard deviation and the category in which the item is found. The expected correct attitude is indicated. The symbol positive (+) is indicated if the expected correct attitude is positive (value close to 5 ) and the symbol negative (-) is indicated if the expected correct attitude is negative (value close to 0 ).

Table 3. Description, mean and deviation of the sample. Variable: Environmental awareness.

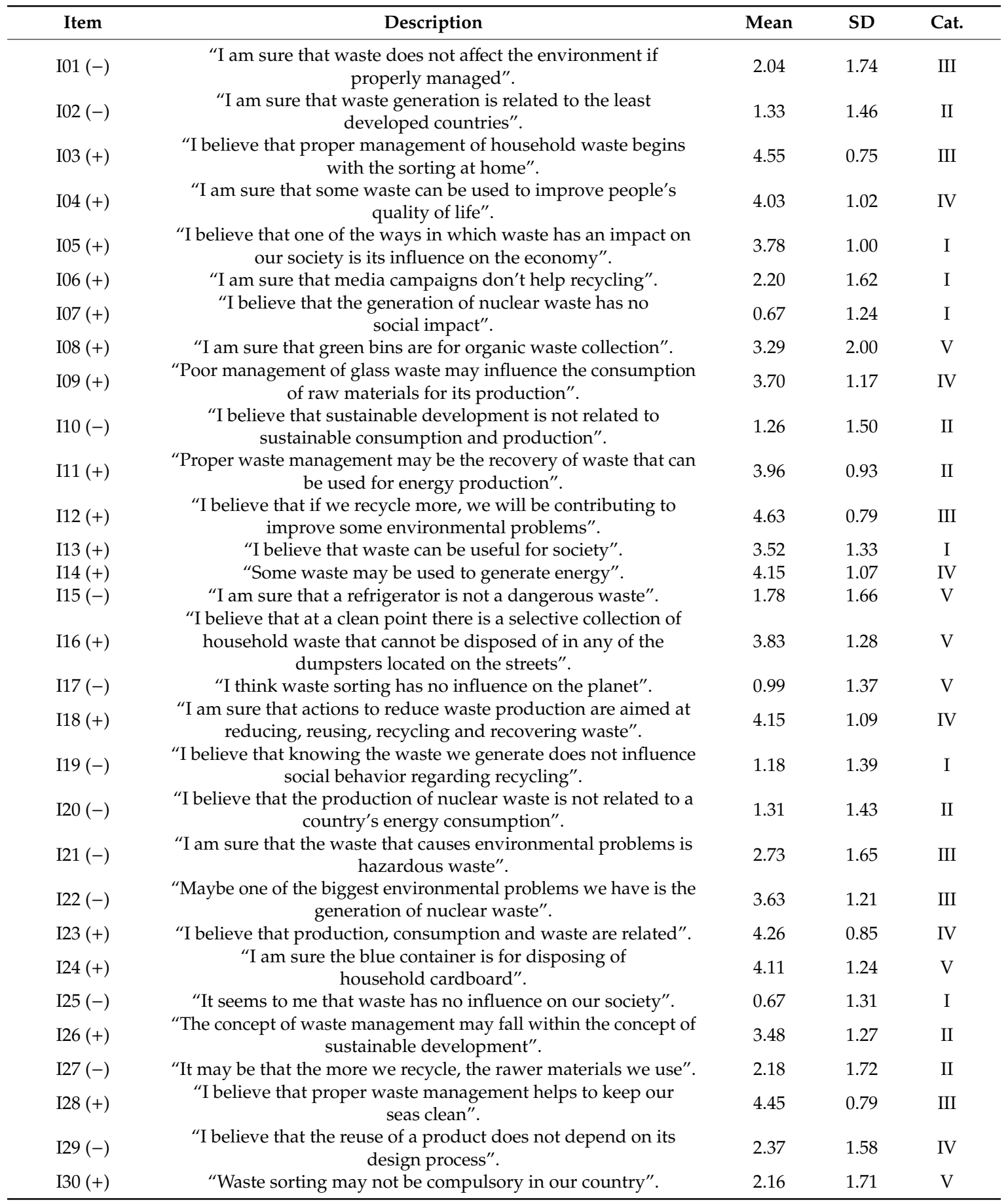


The results shown in Table 3 seem to indicate that future teachers in the sample generally show an adequate level of environmental awareness, with a positive attitude towards the integration of content on sustainable development in their future teaching work, as indicated by other authors [68,69]. Specifically, the results shown in Table 3 suggest that the attitude of future teachers in the sample towards sustainable waste management is generally positive. In other words, high scores have been obtained for those issues for which a positive attitude is expected from the sample (mean values close to 5). Particularly, this is what was obtained in items I03, I12, I14, I18 or I23 among others. It is also observed that in those questions in which the students should show disagreement (mean values close to 0 ) low mean scores have been obtained, some examples being items I02, I07, I17, I19 or I25, among others. Likewise, as we can see in Table 3, negative attitudes should have been obtained from the students (mean value close to 0) towards the category III "Awareness and Ethics" items I01 (with a mean value of 2.04), I21 (with a mean value of 2.73) and I22 (with a mean value of 3.63). The same is true for item I29 of category IV "Technological Development" with an average of 2.37 points, since these are statements that should generate an attitude of disagreement or rejection and lower scores should have been obtained. On the contrary, a positive attitude should have been recorded in item I06 of category I "Waste and Society" but the average response is 2.2 points. Similarly, in question I30 belonging to category V "Typology", an average of 2.16 points was obtained despite it being an item referring to a positive attitude, that is, its expected value should be close to 5 . It should also be noted that the item that obtains the highest average score is I12 referring to a positive attitude and with 4.63 points, and the item that obtains the lowest score is I07 referring to a negative attitude and with a score of 0.673 .

Tables 4-8 show the absolute frequency and percentage obtained for each item grouped into categories. Table 4 shows the results for Category I "Waste and Society".

Table 4. Absolute frequency and percentage of responses for items in Category I, Waste and Society. Variable: Environmental awareness.

\begin{tabular}{|c|c|c|c|c|c|c|c|c|c|c|c|c|}
\hline $\begin{array}{c}\text { Waste and Society } \\
\text { (CAT I) }\end{array}$ & \multicolumn{2}{|c|}{ I05 } & \multicolumn{2}{|c|}{ I06 } & \multicolumn{2}{|c|}{ I07 } & \multicolumn{2}{|c|}{ I13 } & \multicolumn{2}{|c|}{ I19 } & \multicolumn{2}{|c|}{ I 25} \\
\hline $\begin{array}{l}\text { Positive (+): Value close to } 5 \\
\text { Negative (-): Value close to } 0\end{array}$ & \multicolumn{2}{|c|}{+} & \multicolumn{2}{|c|}{+} & \multicolumn{2}{|c|}{-} & \multicolumn{2}{|c|}{+} & \multicolumn{2}{|c|}{-} & \multicolumn{2}{|c|}{ - } \\
\hline Range & $\mathrm{Fi}$ & $\%$ & $\mathrm{Fi}$ & $\%$ & $\mathrm{Fi}$ & $\%$ & $\mathrm{Fi}$ & $\%$ & $\mathrm{Fi}$ & $\%$ & $\mathrm{Fi}$ & $\%$ \\
\hline 0 & 2 & 1.3 & 34 & 21.3 & 112 & 70.0 & 8 & 5.0 & 78 & 48.8 & 116 & 72.5 \\
\hline 1 & 3 & 1.9 & 25 & 15.6 & 15 & 9.4 & 4 & 2.5 & 22 & 13.8 & 12 & 7.5 \\
\hline 2 & 4 & 2.5 & 27 & 16.9 & 17 & 10.6 & 15 & 9.4 & 24 & 15.0 & 17 & 10.6 \\
\hline 3 & 51 & 31.9 & 39 & 24.4 & 6 & 3.8 & 49 & 30.6 & 28 & 17.5 & 5 & 3.1 \\
\hline 4 & 58 & 36.3 & 18 & 11.3 & 5 & 3.1 & 37 & 23.1 & 4 & 2.5 & 3 & 1.9 \\
\hline 5 & 42 & 26.3 & 17 & 10.6 & 4 & 2.5 & 47 & 29.4 & 4 & 2.5 & 7 & 4.4 \\
\hline Total & 160 & 100 & 160 & 100 & 159 & 99.4 & 160 & 100 & 160 & 100 & 160 & 100 \\
\hline
\end{tabular}

Table 5. Absolute frequency and percentage of responses for items in Category II, Normative and Economy. Variable: Environmental awareness.

\begin{tabular}{|c|c|c|c|c|c|c|c|c|c|c|c|c|}
\hline $\begin{array}{c}\text { Normative and Economy } \\
\text { (CAT II) }\end{array}$ & \multicolumn{2}{|c|}{ I02 } & \multicolumn{2}{|c|}{ I10 } & \multicolumn{2}{|c|}{ I11 } & \multicolumn{2}{|c|}{$\mathbf{I 2 0}$} & \multicolumn{2}{|c|}{ I26 } & \multicolumn{2}{|c|}{ I27 } \\
\hline tive $(+)$ Value close to 5 & \multicolumn{2}{|c|}{-} & \multicolumn{2}{|c|}{-} & \multicolumn{2}{|c|}{+} & \multirow{2}{*}{\multicolumn{2}{|c|}{ - }} & \multicolumn{2}{|c|}{+} & \\
\hline ative (-): Value close to 0 & & & & & & & & & & & & \\
\hline Range & $\mathrm{Fi}$ & $\%$ & $\mathrm{Fi}$ & $\%$ & $\mathrm{Fi}$ & $\%$ & $\mathrm{Fi}$ & $\%$ & $\mathrm{Fi}$ & $\%$ & $\mathrm{Fi}$ & $\%$ \\
\hline 0 & 74 & 46.3 & 76 & 47.5 & - & - & 71 & 44.4 & 7 & 4.4 & 49 & 30.6 \\
\hline 1 & 18 & 11.3 & 25 & 15.6 & 1 & 0.6 & 23 & 14.4 & 2 & 1.3 & 8 & 5.0 \\
\hline 2 & 25 & 15.6 & 19 & 11.9 & 9 & 5.6 & 27 & 16.9 & 20 & 12.5 & 23 & 14.4 \\
\hline 3 & 31 & 19.4 & 24 & 15.0 & 39 & 24.4 & 25 & 15.6 & 51 & 31.9 & 39 & 24.4 \\
\hline 4 & 8 & 5.0 & 9 & 5.6 & 56 & 35.0 & 11 & 6.9 & 38 & 23.8 & 27 & 16.9 \\
\hline 5 & 4 & 2.5 & 6 & 3.8 & 55 & 34.4 & 3 & 1.9 & 42 & 26.3 & 14 & 8.8 \\
\hline Total & 160 & 100 & 159 & 99,4 & 160 & 100 & 160 & 100 & 160 & 100 & 160 & 100 \\
\hline
\end{tabular}


Table 6. Absolute frequency and percentage of responses for items in Category III; Awareness and Ethics. Variable: Environmental awareness.

\begin{tabular}{|c|c|c|c|c|c|c|c|c|c|c|c|c|}
\hline $\begin{array}{l}\text { Awareness and Ethics } \\
\text { (CAT III) }\end{array}$ & \multicolumn{2}{|c|}{ I01 } & \multicolumn{2}{|c|}{ I03 } & \multicolumn{2}{|c|}{ I12 } & \multicolumn{2}{|c|}{ I21 } & \multicolumn{2}{|c|}{$\mathbf{I 2 2}$} & \multicolumn{2}{|c|}{ I28 } \\
\hline Expected Correct Attitude & \multirow{2}{*}{\multicolumn{2}{|c|}{ - }} & & & \multirow{2}{*}{\multicolumn{2}{|c|}{+}} & \multirow{2}{*}{\multicolumn{2}{|c|}{ - }} & \multirow{2}{*}{\multicolumn{2}{|c|}{ - }} & \multirow{2}{*}{\multicolumn{2}{|c|}{+}} \\
\hline Positive (+): Value close to 5 & & & & . & & & & & & & & \\
\hline Range & $\mathrm{Fi}$ & $\%$ & $\mathrm{Fi}$ & $\%$ & $\mathrm{Fi}$ & $\%$ & $\mathrm{Fi}$ & $\%$ & $\mathrm{Fi}$ & $\%$ & $\mathrm{Fi}$ & $\%$ \\
\hline 0 & 55 & 34.4 & - & - & 1 & 0.6 & 28 & 17.5 & 4 & 2.5 & 1 & 0.6 \\
\hline 1 & 12 & 7.5 & 1 & 0.6 & 1 & 0.6 & 11 & 6.9 & 3 & 1.9 & - & - \\
\hline 2 & 14 & 8.8 & 2 & 1.3 & 3 & 1.9 & 19 & 11.9 & 17 & 10.6 & 1 & 0.6 \\
\hline 3 & 41 & 25.6 & 13 & 8.1 & 6 & 3.8 & 40 & 25.0 & 49 & 30.6 & 18 & 11.3 \\
\hline 4 & 26 & 16.3 & 36 & 22.5 & 28 & 17.5 & 39 & 24.4 & 38 & 23.8 & 43 & 26.9 \\
\hline 5 & 12 & 7.5 & 108 & 67.5 & 120 & 75.0 & 22 & 13.8 & 49 & 30.6 & 97 & 60.6 \\
\hline Total & 160 & 100 & 160 & 100 & 159 & 99.4 & 159 & 99.4 & 160 & 100 & 160 & 100 \\
\hline
\end{tabular}

Table 7. Absolute frequency and percentage of responses for items in Category IV, Technical Development. Variable: Environmental awareness.

\begin{tabular}{|c|c|c|c|c|c|c|c|c|c|c|c|c|}
\hline $\begin{array}{c}\text { Technological Development } \\
\text { (CAT IV) }\end{array}$ & \multicolumn{2}{|c|}{ I04 } & \multicolumn{2}{|c|}{ I09 } & \multicolumn{2}{|c|}{ I14 } & \multicolumn{2}{|c|}{ I18 } & \multicolumn{2}{|c|}{123} & \multicolumn{2}{|c|}{ I29 } \\
\hline Expected Correct Attitude & \multirow{2}{*}{\multicolumn{2}{|c|}{+}} & \multirow{2}{*}{\multicolumn{2}{|c|}{+}} & \multirow{2}{*}{\multicolumn{2}{|c|}{+}} & \multirow{2}{*}{\multicolumn{2}{|c|}{+}} & \multirow{2}{*}{\multicolumn{2}{|c|}{+}} & \\
\hline Positive (+): Value close to 5 & & & & & & & & & & & & \\
\hline & & & & & & & & & & & & \\
\hline Range & $\mathrm{F} 1$ & $\%$ & $\begin{array}{ll}\mathrm{F} 1 \\
3\end{array}$ & $\%$ & $\begin{array}{c}\mathrm{F} 1 \\
2\end{array}$ & $\%$ & $\begin{array}{ll}\mathrm{F} 1 \\
3\end{array}$ & $\%$ & F1 & $\%$ & $\begin{array}{l}\mathrm{F} 1 \\
33\end{array}$ & $\%$ \\
\hline 0 & 1 & 0.6 & 3 & 1.9 & 2 & 1.3 & 3 & 1.9 & 1 & 0.6 & 33 & 20.6 \\
\hline 1 & 3 & 1.9 & 3 & 1.9 & 3 & 1.9 & 2 & 1.3 & - & - & 14 & 8.8 \\
\hline 2 & 6 & 3.8 & 12 & 7.5 & 8 & 5.0 & 7 & 4.4 & 3 & 1.9 & 23 & 14.4 \\
\hline 3 & 34 & 21.3 & 55 & 34.4 & 19 & 11.9 & 22 & 13.8 & 24 & 15.0 & 57 & 35.6 \\
\hline 4 & 51 & 31.9 & 33 & 20.6 & 51 & 31.9 & 47 & 29.4 & 55 & 34.4 & 16 & 10.0 \\
\hline 5 & 65 & 40.6 & 53 & 33.1 & 76 & 47.5 & 79 & 49.4 & 77 & 48.1 & 17 & 10.6 \\
\hline Total & 160 & 100 & 159 & 99.4 & 159 & 99.4 & 160 & 100 & 160 & 100 & 160 & 100 \\
\hline
\end{tabular}

Table 8. Absolute frequency and percentage of responses for items in Category V, Typology. Variable: Environmental awareness.

\begin{tabular}{|c|c|c|c|c|c|c|c|c|c|c|c|c|}
\hline $\begin{array}{l}\text { Typology } \\
\text { (CAT V) }\end{array}$ & \multicolumn{2}{|c|}{ I08 } & \multicolumn{2}{|c|}{ I15 } & \multicolumn{2}{|c|}{ I16 } & \multicolumn{2}{|c|}{ I17 } & \multicolumn{2}{|c|}{$\mathrm{I} 24$} & \multicolumn{2}{|c|}{ I30 } \\
\hline pected Correct Attitude & \multirow{2}{*}{\multicolumn{2}{|c|}{+}} & \multirow{2}{*}{\multicolumn{2}{|c|}{-}} & \multirow{2}{*}{\multicolumn{2}{|c|}{+}} & \multirow{2}{*}{\multicolumn{2}{|c|}{ - }} & \multirow{2}{*}{\multicolumn{2}{|c|}{+}} & \multirow{2}{*}{\multicolumn{2}{|c|}{+}} \\
\hline Positive (+): Value close to 5 & & & & & & & & & & & & \\
\hline Range & $\mathrm{Fi}$ & $\%$ & $\mathrm{Fi}$ & $\%$ & $\mathrm{Fi}$ & $\%$ & $\mathrm{Fi}$ & $\%$ & $\mathrm{Fi}$ & $\%$ & $\mathrm{Fi}$ & $\%$ \\
\hline 0 & 32 & 20.0 & 60 & 37.5 & 5 & 3.1 & 93 & 58.1 & 5 & 3.1 & 46 & 28.7 \\
\hline 1 & 10 & 6.3 & 14 & 8.8 & 7 & 4.4 & 20 & 12.5 & 3 & 1.9 & 11 & 6.9 \\
\hline 2 & 8 & 5.0 & 20 & 12.5 & 8 & 5.0 & 13 & 8.1 & 8 & 5.0 & 23 & 14.4 \\
\hline 3 & 13 & 8.1 & 45 & 28.1 & 30 & 18.8 & 24 & 15.0 & 23 & 14.4 & 52 & 32.5 \\
\hline 4 & 23 & 14.4 & 8 & 5.0 & 48 & 30.0 & 9 & 5.6 & 34 & 21.3 & 4 & 2.5 \\
\hline 5 & 74 & 46.3 & 13 & 8.1 & 61 & 38.1 & 1 & 0.6 & 87 & 54.4 & 23 & 14.4 \\
\hline Total & 160 & 100 & 160 & 100 & 159 & 99.4 & 160 & 100 & 160 & 100 & 159 & 99.4 \\
\hline
\end{tabular}

As we can see in Table 4, all items in this category obtain their maximum percentage in the expected ranges. However, it should be noted that in I06 24.4\% of students selected option 3, suggesting that teachers were hesitant about the right attitude to adopt.

Table 5 shows the frequencies and percentages of students choosing each range value in Category II "Normative and Economy".

Table 5 shows that the attitudes expressed by a large part of future teachers towards the concept of waste related to the economy and regulations are not entirely favorable. Specifically, in the I27 the percentage of students is very much distributed among the different ranges, and $50 \%$ of the subjects show a positive attitude towards this item from which a negative attitude was expected from the 
participants. Likewise, attitudes contrary to what was expected from almost $30 \%$ of students are found in some items of this category.

Table 6 shows the frequencies and percentages of students choosing each range value in Category III "Awareness and Ethics".

As shown in Table 6, items I01 and I21 have widely dispersed scores across all ranges. Specifically, in item I01 the range that obtains the highest percentage (3 "Somewhat Agree") is far from the one that represents the desired attitude, which would be 0 "Completely disagree". In the case of I 21 only $36 \%$ of the sample selects the appropriate ranges. Likewise, the results in I22 are not as expected either, since more than $60 \%$ of those surveyed show an attitude contrary to that sought.

Table 7 shows the frequencies and percentages of students choosing each range value in Category IV "Technological Development".

Table 7 shows that all items, except for I29, obtain high percentages in the ranges sought, which reflects that in this category teachers in training would project correct attitudes in the classrooms when explaining these concepts. In the case of I29, it is worth noting that $55 \%$ of the sample reveals inappropriate attitudes.

Table 8 shows the frequencies and percentages of students choosing each range value in the Category V "Typology".

As can be seen in Table 8, most teachers in training have favorable attitudes towards the content of residue in relation to the typology category. However, research from [70] found that secondary and high school students do not know what "clean points" are, as only $14 \%$ of respondents associated them with places to collect household waste that cannot be disposed of in regular containers. On the contrary, the results obtained in items I08 and I30 (referring to the types of containers and their use) are striking because it is observed that more than $30 \%$ of students choose the options that are related to a negative attitude. In this sense, it is important to highlight again the studies of [70] because, unlike our results, students of Compulsory Secondary Education (CSE) and Baccalaureate state that they know what waste is deposited in each of the containers for recycling. In general, the results obtained indicate that teachers in training have favorable attitudes towards the environment in the field of waste, although it is true that worse attitudinal results are observed in the items of the categories Normative and Economy (CAT II), Awareness and Ethics (CAT III) and Typology (CAT V). In contrast, the categories with the best results in terms of attitudes are Waste and Society (CAT I) and Technological Development (CAT IV). As indicated above, in many of the items a correct attitude can be seen in a high percentage of the sample, but negative results have also been found in three of the five categories established, so we can understand that teachers in training are not clear about the attitude they would take in the case of explaining these concepts to their future students.

In order to analyze the existence of statistically significant differences in the attitudes of both sets, the Student's t parametric test was used when the necessary requirements were checked. The results are shown in Table 9.

As can be seen in Table 9, statistically significant differences were obtained in most of the items of the questionnaire, in favor of secondary education teachers. Specifically, these differences appear in five of the six items of category II (Normative and Economy) and in three of the six items of categories I (Waste and Society), III (Awareness and Ethics), IV (Technological Development) and V (Typology). In all these cases, the average values obtained confirm that future primary education teachers show a worse attitude toward explaining content than future secondary education teachers. These results allow us to accept Hypothesis $\mathrm{H} 1$ of the research "teachers in training in the sample have the right attitude to develop their future teaching work in the field of waste, with statistically significant differences being found depending on the degree taken". 
Table 9. Variable: Environmental Awareness. Student's t-test. Primary vs. secondary education teachers in training.

\begin{tabular}{cccccccc}
\hline & & df & $\begin{array}{c}\text { Sig. } \\
\text { (2-tailed) }\end{array}$ & $\begin{array}{c}\text { Mean } \\
\text { Difference }\end{array}$ & $\begin{array}{c}\text { Std. Error } \\
\text { Difference }\end{array}$ & $\begin{array}{c}\text { 95\% Confidence Interval of } \\
\text { the Difference }\end{array}$ \\
\cline { 6 - 8 } & & & & & & Lower & Upper \\
\hline I02 & -3.005 & 158 & $0.003^{*}$ & -0.77199 & 0.25690 & -1.27939 & -0.26460 \\
I03 & 2.155 & 158 & $0.033^{*}$ & 0.28733 & 0.13336 & 0.02393 & 0.55073 \\
I06 & -2.437 & 158 & $0.016^{*}$ & -0.69935 & 0.28697 & -1.26615 & -0.13255 \\
I08 & -2.204 & 158 & $0.029^{*}$ & -0.78571 & 0.35652 & -1.48988 & -0.08155 \\
I10 & -2.953 & 157 & $0.004^{*}$ & -0.77961 & 0.26398 & -1.30102 & -0.25820 \\
I11 & 2.002 & 158 & $0.047^{*}$ & 0.33293 & 0.16634 & 0.00440 & 0.66146 \\
I13 & 2.451 & 158 & $0.015^{*}$ & 0.57950 & 0.23640 & 0.11259 & 1.04641 \\
I15 & -2.762 & 158 & $0.006^{*}$ & -0.80952 & 0.29311 & -1.38845 & -0.23060 \\
I17 & -3.489 & 158 & $0.001^{*}$ & -0.83091 & 0.23817 & -1.30131 & -0.36051 \\
I18 & 2.230 & 158 & $0.027^{*}$ & 0.43382 & 0.19456 & 0.04954 & 0.81810 \\
I19 & -2.338 & 158 & $0.021^{*}$ & -0.57708 & 0.24678 & -1.06450 & -0.08966 \\
I22 & -2.169 & 158 & $0.032^{*}$ & -0.46852 & 0.21605 & -0.89524 & -0.04180 \\
I23 & 2.488 & 158 & $0.014^{*}$ & 0.37813 & 0.15196 & 0.07799 & 0.67827 \\
I26 & 4.424 & 158 & $0.000^{*}$ & 0.96166 & 0.21740 & 0.53229 & 1.39104 \\
I27 & -5.935 & 158 & $0.000^{*}$ & -1.66626 & 0.28075 & -2.22076 & -1.11176 \\
I28 & 3.198 & 158 & $0.002^{*}$ & 0.44673 & 0.13970 & 0.17081 & 0.72265 \\
I29 & -4.412 & 158 & $0.000^{*}$ & -1.18644 & 0.26891 & -1.71756 & -0.65532 \\
\hline
\end{tabular}

\subsection{Results Referring to the Variable Level of Knowledge of the Teachers in Training}

The above data can be linked to the level of prior knowledge of the participating sample on the concept of waste considering the established categories. Therefore, in order to establish a relationship between the variable level of environmental awareness and the level of knowledge of the teacher in training, the results obtained in the previous study [52] have been considered. This research concluded that there is a clear lack of knowledge and training on the part of future secondary school teachers with respect to this concept. Table 10 shows a comparison of the results obtained by future secondary education teachers [52] with those obtained by the sample of future primary education teachers in the knowledge level variable according to the different categories established. The descriptive statistics are presented, mean (out of 1 point), standard deviation and standard error of the mean. Likewise, Table 11 shows the inferential analysis carried out by means of the Student's t-test to analyze the statistically significant differences between both groups in the different categories: Waste and Society (WS); Normative and Economy; (NE) Awareness and Ethics (AE) and Typology (T).

Table 10. Variable: Level of knowledge. Descriptive statistics. Secondary education vs. primary education teachers in training.

\begin{tabular}{ccccc}
\hline Category & Group & Mean & $\begin{array}{c}\text { Std. } \\
\text { Deviation }\end{array}$ & $\begin{array}{c}\text { Std. Error } \\
\text { Mean }\end{array}$ \\
\hline Waste and Society & Secondary & 0.67 & 0.217 & 0.025 \\
(WS) & Primary & 0.42 & 0.166 & 0.015 \\
Normative and Economy & Secondary & 0.39 & 0.194 & 0.022 \\
(NE) & Primary & 0.24 & 0.180 & 0.016 \\
Awareness and Ethics & Secondary & 0.56 & 0.194 & 0.022 \\
(AE) & Primary & 0.49 & 0.179 & 0.016 \\
Typology & Secondary & 0.38 & 0.164 & 0.019 \\
(T) & Primary & 0.15 & 0.142 & 0.012 \\
\hline
\end{tabular}


Table 11. Variable: Level of knowledge. Student's t-test. Secondary education vs. primary education teachers in training.

\begin{tabular}{|c|c|c|c|c|c|c|c|}
\hline \multirow[b]{2}{*}{ Category } & \multirow[t]{2}{*}{$\mathbf{t}$} & \multirow[t]{2}{*}{$\mathrm{df}$} & \multirow{2}{*}{$\begin{array}{l}\text { Sig. } \\
\text { (2-tailed) }\end{array}$} & \multirow{2}{*}{$\begin{array}{c}\text { Mean } \\
\text { Difference }\end{array}$} & \multirow{2}{*}{$\begin{array}{l}\text { Std. Error } \\
\text { Difference }\end{array}$} & \multicolumn{2}{|c|}{$\begin{array}{c}\text { 95\% Confidence Interval of } \\
\text { the Difference }\end{array}$} \\
\hline & & & & & & Lower & Upper \\
\hline WS & 9.224 & 191 & $0.000^{*}$ & 0.25675 & 0.02784 & 0.20185 & 0.31166 \\
\hline $\mathrm{NE}$ & 5.579 & 191 & $0.000^{*}$ & 0.15458 & 0.02771 & 0.09993 & 0.20923 \\
\hline $\mathrm{AE}$ & 2.783 & 191 & $0.006^{*}$ & 0.07670 & 0.02756 & 0.02234 & 0.13106 \\
\hline $\mathrm{T}$ & 9.911 & 191 & $0.000^{*}$ & 0.22258 & 0.02246 & 0.17828 & 0.26688 \\
\hline
\end{tabular}

As can be seen in Table 10, which presents the mean over 1 of the level of knowledge of the teachers in training in the different categories, the participating sample presents a low level of knowledge in the concept of waste. A better mastery of the contents in Category I (Waste and Society) and Category III (Awareness and Ethics) is observed in both groups. On the contrary, in both future primary and secondary education teachers, the level of knowledge is lower in the concepts related to Category II (Normative and Economy) and Category V (Typology). These results are related to those obtained by other researchers [71] who show the low level of environmental knowledge of first and fourth-year university students in urban and regional planning and environmental engineering.

When comparing the results between academic groups (Table 11), it should be noted that the level of knowledge shown by primary education teachers in training is lower than that shown by secondary education teachers in training in all the categories analyzed. Specifically, statistically significant differences are found (Sig. < 0.05) in all the categories analyzed in favor of the group of future secondary education teachers. The previous results lead to the acceptance of the Hypothesis $\mathrm{H} 2$ proposed in the research "Future teachers in the sample have a low level of knowledge about the concept of waste in each of the established categories, with statistically significant differences being found depending on the degree taken". Likewise, these results are related to the level of environmental awareness of these groups shown in the previous section. In the sample studied, future primary school teachers show a more negative attitude or lower level of environmental awareness than future secondary school teachers. These differences are more noticeable in those contents in which the level of knowledge is lower, such as in categories Normative and Economy (CAT II) or Typology (CAT V).

\subsection{Environmental Awareness Results according to the Gender Variable}

Additionally, an inferential analysis was carried out based on the gender of the participating sample. The idea is to check whether sustainable attitudes towards waste vary according to this variable. The results obtained reveal that, generally, the attitudes shown by the participating sample do not change according to the subject's gender, although it is true that statistically significant differences have been found in some of the survey's questions in favor of women in most cases, thus coinciding with the contributions of other research $[45,72,73]$.

Table 12 shows those questions in which statistically significant differences between genders were found, in favor of women in I19, I20 and I21 (items in which a negative attitude was expected from the subjects) and in favor of men in I26 (item in which a positive attitude was expected from the respondents).

The above data lead us to partially accept Hypothesis H3 "women show greater environmental awareness than men regarding the concept of waste in the sample" since significant differences have been found in environmental attitudes in favor of the female collective in some cases. 
Table 12. Student's t-test. Variable: Environmental awareness according to gender. Women vs. men.

\begin{tabular}{cccccccc}
\hline & & & \multirow{2}{*}{$\begin{array}{c}\text { Sig. } \\
\text { (2-tailed) }\end{array}$} & $\begin{array}{c}\text { Mean } \\
\text { Difference }\end{array}$ & $\begin{array}{c}\text { Std. Error } \\
\text { Difference }\end{array}$ & \multicolumn{2}{c}{$\begin{array}{c}\text { 95\% Confidence Interval of } \\
\text { the Difference }\end{array}$} \\
\cline { 5 - 8 } & & & & & Lower & Upper \\
\hline $\mathrm{I} 19$ & 2.508 & 158 & $0.013^{*}$ & 0.61743 & 0.24617 & 0.13123 & 1.10363 \\
$\mathrm{I} 20$ & 2.228 & 158 & $0.027^{*}$ & 0.56860 & 0.25520 & 0.06456 & 1.07264 \\
$\mathrm{I} 21$ & 2.203 & 157 & $0.029^{*}$ & 0.65172 & 0.29580 & 0.06746 & 1.23597 \\
$\mathrm{I} 26$ & 2.100 & 158 & $0.037^{*}$ & 0.47740 & 0.22731 & 0.02843 & 0.92637 \\
\hline
\end{tabular}

\subsection{Results Referring to Emotional and Teacher Self-Efficacy Level Variables}

Table 13 shows the averages of positive and negative emotions for each of the categories considered, for both primary and secondary education teachers in training.

Table 13. Average of positive and negative emotions in each category.

\begin{tabular}{|c|c|c|c|c|c|c|c|c|}
\hline \multirow[b]{2}{*}{$\begin{array}{l}\text { Group } \backslash \text { emotions } \\
\text { Secondary }\end{array}$} & \multicolumn{2}{|c|}{$\begin{array}{c}\text { CAT I } \\
\text { (Waste and Society) }\end{array}$} & \multicolumn{2}{|c|}{$\begin{array}{c}\text { CAT II } \\
\text { (Norm. and Eco.) }\end{array}$} & \multicolumn{2}{|c|}{$\begin{array}{c}\text { CAT III } \\
\text { (Awa. and Ethics) }\end{array}$} & \multicolumn{2}{|c|}{$\begin{array}{c}\text { CAT V } \\
\text { (Typology) }\end{array}$} \\
\hline & + & - & + & - & + & - & + & - \\
\hline $\begin{array}{l}\text { education teachers } \\
\text { in training }\end{array}$ & 5.6 & 2.7 & 4.3 & 3 & 6 & 2.5 & 5.3 & 2.7 \\
\hline $\begin{array}{l}\text { Primary education } \\
\text { teachers in } \\
\text { training }\end{array}$ & 6 & 2.8 & 4.9 & 3 & 6.4 & 2.4 & 5.5 & 2.6 \\
\hline Total sample & 5.9 & 2.8 & 4.7 & 3.0 & 6.2 & 2.5 & 5.4 & 2.6 \\
\hline
\end{tabular}

The analysis of the data about the emotional variables (Table 13) shows that the manifestation of positive emotions in the participating sample prevails over negative ones when teaching the contents on waste referring to all the established categories, independently of the degree studied. However, it is the contents of Category I Waste and Society and Category III Awareness and Ethics that produce greater emotional well-being in those surveyed compared with the rest of the categories. Note how these emotional results coincide with those obtained in the level of knowledge and in the level of environmental awareness mentioned above. It seems logical that the sample shows more negative emotions and less positive emotions when compared to the contents in which it shows a low level of knowledge. On the contrary, the sample shows more positive emotions and less negative ones when teaching contents in which it shows a higher level of knowledge. In addition, it was decided to check whether there were statistically significant differences between academic groups in relation to the emotions expressed. The inferential statistical analysis carried out with the Student's t-test between academic groups revealed that there were no statistically significant differences at the emotional level in any of the categories. Specifically, the significance values found are shown in Table 14.

Table 14. Sig. values (Student's t-test) in the emotional variable (primary education vs. secondary education teachers in training).

\begin{tabular}{ccccc}
\hline Waste and Society & $\begin{array}{c}\text { Normative and } \\
\text { Economy }\end{array}$ & $\begin{array}{c}\text { Awareness and } \\
\text { Ethics }\end{array}$ & Typology \\
\hline $\begin{array}{c}\text { Positive emotions } \\
\text { Negative emotions }\end{array}$ & Sig. $=0.365$ & Sig. $=0.161$ & Sig. $=0.417$ & Sig. $=0.509$ \\
\hline
\end{tabular}


Table 13 includes in its last row the mean value of positive and negative emotions considering the whole sample in order to carry out an inferential statistical analysis and check if there are statistically significant differences in the level of manifestation of positive emotions versus negative emotions considering the whole participating sample. Table 15 shows the results obtained by the entire sample in the Student's t-test, distinguishing by category.

Table 15. T-test of positive versus negative emotions by category.

\begin{tabular}{|c|c|c|c|c|c|c|c|}
\hline & \multirow[t]{2}{*}{$\mathbf{t}$} & \multirow[t]{2}{*}{ df } & \multirow[t]{2}{*}{$\begin{array}{c}\text { Sig. } \\
\text { (2-tailed) }\end{array}$} & \multirow[t]{2}{*}{$\begin{array}{c}\text { Mean } \\
\text { Difference }\end{array}$} & \multirow[t]{2}{*}{$\begin{array}{l}\text { Std. Error } \\
\text { Difference }\end{array}$} & \multicolumn{2}{|c|}{$\begin{array}{l}\text { 95\% Confidence } \\
\text { Interval of the } \\
\text { Difference }\end{array}$} \\
\hline & & & & & & Lower & Upper \\
\hline Category I & 13.475 & 374 & $0.000^{*}$ & 3.07128 & 0.22792 & 2.62311 & 3.51944 \\
\hline Category II & 7.049 & 374 & $0.000^{*}$ & 1.68546 & 0.23911 & 1.21529 & 2.15563 \\
\hline Category III & 15.934 & 374 & $0.000^{*}$ & 3.77855 & 0.23714 & 3.31225 & 4.24484 \\
\hline Category V & 11.295 & 374 & $0.000^{*}$ & 2.81011 & 0.24878 & 2.32092 & 3.29930 \\
\hline
\end{tabular}

The results shown in Table 15 reveal that there are statistically significant differences (Sig. $<0.05)$ in all the cases analyzed, that is, the future teachers in the sample show more positive emotions than negative ones about the teaching of contents on waste in all its categories, this difference being significant. The above data lead us to accept Hypothesis H4 of the research "Teaching the concept of waste mainly generates positive emotions and attitudes in future teachers in the sample" because statistically significant differences have been found in the manifestation of positive emotions as opposed to negative ones on the part of the participating sample.

Regarding the analysis of the level of teacher self-efficacy $[64,74]$ in relation to the teaching of content on waste, it should be noted that, as with the cognitive and emotional domains, future teachers in the sample are more competent in content related to Category I (Waste and Society) and Category II (Awareness and Ethics). That is, they show a higher level of teaching self-efficacy in those categories where they show a higher level of knowledge and where they manifest more positive emotions. In contrast, the level of teaching self-efficacy decreases when explaining content related to the categories on Normative and Economy (CAT II) and Typology (CAT V). In these categories the level of teaching self-efficacy is lower, as was the level of knowledge, the manifestation of positive emotions was lower, and the manifestation of negative emotions was higher. The results on the level of teacher self-efficacy are shown in Table 16.

Table 16. Level of teaching self-efficacy (score out of ten).

\begin{tabular}{ccccc}
\hline & $\begin{array}{c}\text { CAT I } \\
\text { (Waste and } \\
\text { Society) }\end{array}$ & $\begin{array}{c}\text { CAT II } \\
\text { (Normative and } \\
\text { Economy) }\end{array}$ & $\begin{array}{c}\text { CAT III } \\
\text { (Awareness and } \\
\text { Ethics) }\end{array}$ & $\begin{array}{c}\text { CAT V } \\
\text { (Typology) }\end{array}$ \\
\hline $\begin{array}{c}\text { Secondary } \\
\text { education teachers } \\
\text { in training }\end{array}$ & 6.5 & 4.2 & 7.3 & 5.8 \\
$\begin{array}{c}\text { Primary education } \\
\text { teachers in training }\end{array}$ & 6.6 & 4.3 & 7.3 & 5.8 \\
Total sample & 6.5 & 4.2 & 7.3 & 5.8 \\
\hline
\end{tabular}

Subsequently, it was decided to test whether there were statistically significant differences between future secondary teachers and those of primary school with respect to the level of teacher self-efficacy shown in each category. The results shown in Table 17 indicate that there are no statistically significant differences (Sig. > 0.05) in this self-efficacy variable according to the degree studied. 
Table 17. Variable: Level of teaching self-efficacy. Student's-t test. Primary education vs. secondary education teachers in training.

\begin{tabular}{lccccccc}
\hline & & & & & & \multicolumn{2}{c}{$\begin{array}{c}\text { 95\% Confidence } \\
\text { Interval of the } \\
\text { Difference }\end{array}$} \\
\hline Category I & -0.343 & 189 & 0.732 & -0.11737 & 0.34237 & -0.79273 & 0.55799 \\
Category II & -0.185 & 189 & 0.853 & -0.07923 & 0.42724 & -0.92200 & 0.76355 \\
Category III & 0.060 & 189 & 0.952 & 0.01878 & 0.31165 & -0.59599 & 0.63355 \\
Category V & 0.011 & 189 & 0.992 & 0.00399 & 0.37656 & -0.73881 & 0.74679 \\
\hline
\end{tabular}

Taking into account that no differences were found in teacher self-efficacy according to the group, an ANOVA test with Tukey's Post-Hoc was carried out, considering the whole participating sample, to check if there are statistically significant differences in the teacher self-efficacy shown according to the category to be taught. Table 18 shows the results obtained in the one-way ANOVA test.

Table 18. One-way ANOVA for the teaching self-efficacy variable according to the category variable.

\begin{tabular}{cccccc}
\hline & Sum of Squares & df & Mean Square & F & Sig. \\
\hline Between groups & 940.810 & 3 & 313.603 & 52.470 & $0.000^{*}$ \\
Within groups & 4542.398 & 760 & 5.977 & & \\
Total & 5483.208 & 763 & & & \\
\hline \multicolumn{7}{c}{ * Sig. $<0.05}$.
\end{tabular}

The results shown in Table 18 reveal that the future teacher in the sample shows greater competence in some categories than in others as statistically significant differences are found. To check between which categories these differences are presented, Table 19 presents the data obtained in the Tukey's Post-Hoc test.

Table 19. Tukey's Post-Hoc for the variable teaching self-efficacy level (variable: categories).

\begin{tabular}{ccccccc}
\hline (I) Category & (J) Category & $\begin{array}{c}\text { Mean } \\
\text { Difference (I-J) }\end{array}$ & Std. Error & Sig. & \multicolumn{2}{c}{$\mathbf{9 5 \% \text { Confidence Interval }}$} \\
\cline { 5 - 7 } & & & & & $\begin{array}{c}\text { Lower } \\
\text { Bound }\end{array}$ & $\begin{array}{c}\text { Upper } \\
\text { Bound }\end{array}$ \\
\hline \multirow{3}{*}{ CI (WS) } & CII (NE) & $2.27749^{*}$ & 0.25017 & $0.000^{*}$ & 1.6334 & 2.9216 \\
& CIII (A) & $-0.71728^{*}$ & 0.25017 & $0.022^{*}$ & -1.3614 & -0.0732 \\
CII (NE) & CV (T) & $0.73822^{*}$ & 0.25017 & $0.017^{*}$ & 0.0941 & 1.3823 \\
CIII (A) & CIII (A) & $-2.99476^{*}$ & 0.25017 & $0.000^{*}$ & -3.6389 & -2.3506 \\
& CV (T) & $-1.53927^{*}$ & 0.25017 & $0.000^{*}$ & -2.1834 & -0.8951 \\
\end{tabular}

The results shown in Table 19 indicate that there are statistically significant differences in the teaching self-efficacy shown by the participants according to the category to be considered. Specifically, the teachers are less competent in teaching content on waste related to Category II Normative and Economy and Category V Typology compared to the rest, as significant differences were found in all these cases. These results were to be expected, considering that in these categories the level of knowledge is lower and there are fewer positive emotions. On the other hand, students were significantly more competent in explaining content related to Category II Awareness and Ethics than the rest of the categories, followed by Category I Waste and Society. In these categories, we also found in the previous section a higher level of knowledge and greater manifestation of positive emotions.

The above results on teacher self-efficacy suggest that the cognitive and affective domains should be explicitly integrated in a science education that addresses sustainability, since as some research 
highlights [75] the affective-cognitive relationship is essential to foster both attitudes and sustainable actions with the environment. Likewise, the data shown allow us to accept the Hypothesis H5 proposed in the research "There are statistically significant differences in the level of teaching self-efficacy of teachers in training in the sample depending on the content to be taught".

\section{Discussion and Conclusions}

The results suggest that future teachers that participated in the study have a positive attitude towards integrating sustainable development into their future teaching work $[68,69]$. In general terms, we can say that future teachers in the sample have attitudes that would favor the teaching of waste in most categories, since the results obtained are generally linked to attitudes that are close to those sought. This supports statements made by other studies [76] that indicate that students have correct attitudes towards environmental education and the issue of municipal solid waste [60]. These results also coincide with those obtained by other researchers [77] who concluded that more than $70 \%$ of the students surveyed in their study considered trash to be an environmental problem and that some measures should be taken as soon as possible. However, we also agree with these authors that very rarely do students recognize how their possible participation could contribute to waste reduction. In the light of these facts, it can be concluded that future teachers in the sample show favorable attitudes towards the conservation of the environment but do not feel involved in the decision-making process and, therefore, adopt a passive role in the face of problems showing difficulties in proposing solutions [70].

In addition, we can also indicate that the degree that the student possesses is binding in order to obtain correct attitudes, since attitudinal differences have been found among those surveyed according to their academic degree, that is, primary education teachers versus secondary education teachers. This may be because the concept of waste appears more frequently in the scientific subjects taken by future teachers at the secondary level, and for this reason they should have more advanced knowledge than the rest of those surveyed. This is in line with other studies [66] that point out that ecological attitudes and beliefs depend on the level of education attained. Gender also influences environmental attitudes because, although the results generally indicate that there is similar awareness between genders, we believe that participating female students show greater attention to the environment and to the events that occur around them compared to male students [72].

Despite an increase in social consciousness towards the improvement and defense of the environment, this does not seem to have been translated into specific behaviors. In other words, high environmental awareness alone does not ensure the implementation of responsible ecological behavior [78]. Logically, environmental education alone cannot improve knowledge about environmental problems and help change our habits [32]. Sustainability issues cut across various academic disciplines, from the natural sciences to the social sciences and humanities, so interdisciplinarity has become a central idea in the field of sustainability science [9,79]. In any case, in order to achieve a change in citizens' attitudes and behavior, it is necessary for this to emanate from the school itself. However, when it comes to transferring the study of waste to the classroom, it is advisable not only to educate in order to achieve a clear perception of the importance of socio-cultural factors in environmental problems [80], but also to promote knowledge of the raw materials that make up products and their possibility of being recycled in order to help decision-making and to encourage a reduction in consumption [81].

Besides, the complexity of the environmental problem cannot be approached from traditional educational approaches, which are excessively theoretical, simplifying and reductionist of reality [82]. With these didactic methodologies it is possible, in the best of cases, for students to increase their level of conceptual knowledge about the environment and environmental problems [11]. This aspect needs to be improved, since the participants in this study show a significant lack of knowledge on the subject, as other studies also point out [83]. However, even if the cognitive domain is improved, these methodologies do not enhance the skills and capacity to know how to act to solve the problems 
of which they have been made aware at a theoretical level [84]. Likewise, the results of some studies show that teachers find it difficult to deal with these issues in the classroom and tend to educate about the environment by developing strategies that are basically oriented towards providing information, even though they claim to be doing environmental education $[85,86]$. In this sense, we should analyze the barriers that exist to achieve pro-environmental behavior and move from merely explanatory procedures to others with greater citizen involvement and debate [87]. If future teachers have positive attitudes towards the environment, their students will also adopt positive attitudes and will automatically be aware of environmental problems [83].

Regarding the difficulties identified, certain limitations related to the number of participants in the study are noted, which restrict the option of extrapolating the results found. In addition, it should be noted that only students from one academic year participated, so it would be interesting to continue collecting samples in subsequent years and to expand the data in this regard. Moreover, a future line of research could also be focused on adapting this previous diagnostic phase to the students of other educational stages, or even carry it out with active teachers, in order to make a comparison of the results between the different groups that make up the education sector. Another limitation to be assessed in the research was the type of design used. As it was a descriptive and non-experimental design, no intervention was carried out to favor the attitudes, knowledge and emotions of the participating sample regarding waste management. Nevertheless, the results give us an idea of what the surveyed future teachers really think and feel about the subject under study. This can be used as a previous step to design and plan a future intervention that motivates them and shows them ways to act in situations that are sometimes complex to face.

The role of education for sustainability must be reflected in current curricula, as previous findings reinforce the importance of working on sustainability at all stages of education [83]. In this sense, we agree with other researchers [56] who indicate that the best way to develop these skills is through cross-curricular work in all subjects. Environmental education strategies should consider the relationship between science, technology, society and environmental knowledge because success and positive attitudes towards these areas of knowledge would increase positive attitudes towards environmental problems. In order to promote social learning within the framework of sustainability, the educational context is extremely relevant. Education must promote critical thinking in all citizens, as well as attitudes and values capable of supporting and giving meaning to responsible attitudes and actions towards the natural environment, both at individual and social levels. If we teachers wish to engage our students, the university must train educational professionals capable of using their knowledge, not only in a scientific context. They must also be capable of responding to environmental problems and social needs, making decisions and carrying out actions consistent with the values of sustainability. Our work as teachers must favor procedures that stimulate student learning in STSE (Science, Technology, Society and Environment), providing them with the conceptual tools that allow them to understand the world in which they live and that their actions have consequences that affect us all.

Considering this interdisciplinarity, activities based on active learning methodologies, such as gamification [88], hands-on activities [89] or those based on research can be very helpful. Active methodologies have a powerful influence on students' interest and awareness and can lead to meaningful and relevant discussions with others around them concerning environmental issues and the need for community action [90]. In addition, educational experiences that include families contribute greatly to enhancing student learning [91]. As some authors point out [92], the process of intergenerational influence can potentially be a powerful means of improving the environmental knowledge, attitudes and behavior of not only children but also adults. Meeting basic human needs, now and in the future, requires a significant change in the thinking, values and actions of all people and institutions with respect to the natural environment. Poor training in scientific content related to sustainability can be a limitation to education and a barrier to changing attitudes. For sustainable knowledge and attitudes to be truly effective, educational actions must be encouraged to involve the 
entire community in their development. Universities, as teaching and research institutions, should be the main agents of change providing answers to the problems and challenges of today's society. Therefore, it will be essential to implement management and decision-making policies that set an example for future teachers at all stages of education, but also for society in general. Society must be committed to the idea that decisions on the scientific landscape or technological transformation cannot be delegated to experts alone, because these are issues that are open to citizens and require strong collective participation. Finally, we consider the need to continue promoting correct attitudes in university students, although we believe that the regulations governing university education in Spain should deal with the concept of waste in different subjects in a more compulsory way [34], as it is currently a very important element in sustainable development and in the training of citizens, mainly from a social and environmental point of view.

Author Contributions: Conceptualization, all authors; methodology, all authors; validation, all authors; formal analysis, M.M.-N. and G.M.-B.; investigation, all authors; resources all authors; data curation, M.M.-N. and G.M.-B.; writing — original draft preparation, all authors; writing—review and editing, all authors; visualization, all authors; supervision, all authors; project administration, G.M.-B.; funding acquisition, G.M.-B. All authors have read and agreed to the published version of the manuscript.

Funding: This research was funded by Junta de Extremadura/Fondo Europeo de Desarrollo Regional, Research Project IB16068, Agencia Estatal de Investigación/Fondo Europeo de Desarrollo Regional, Research Project EDU2016-77007-R and Junta de Extremadura/Fondo Europeo de Desarrollo Regional, Grant GR18004.

Conflicts of Interest: The authors declare no conflict of interest. The funders had no role in the design of the study; in the collection, analyses or interpretation of data; in the writing of the manuscript or in the decision to publish the results.

\section{References}

1. UNESCO. Transforming Our World: The 2030 Agenda for Sustainable Development; UNESCO: Paris, France, 2015; Available online: https://sustainabledevelopment.un.org/post2015/transformingourworld (accessed on 8 January 2019).

2. Song, Q.; Li, J.; Zeng, X. Minimizing the increasing solid waste through zero waste strategy. J. Clean. Prod. 2015, 104, 199-210. [CrossRef]

3. Glažar, S.A.; Vrtačnik, M.; Bačnik, A. Primary school children's understanding of municipal waste processing. Environ. Educ. Res. 1998, 4, 299-308. [CrossRef]

4. Martín, M. Cultura científica y participación ciudadana: Materiales para la educación CTS. Rev. Iber. Cienc. Tec. Soc. 2005, 2, 123-135.

5. Mora, W.M. Educación ambiental y educación para el desarrollo sostenible ante la crisis planetaria: Demandas a los procesos formativos del profesorado. TED 2009, 7-35. [CrossRef]

6. Giljum, S.; Lutz, C.; Jungnitz, A.; Bruckner, M.; Hinterberger, F. Global Dimensions of European Natural Resource Use; First Results from the Global Resource Accounting Model (GRAM). Sustainable Europe Research Institute (SERI) and Institute for Economic Structures Research (GWS). 2008. Available online: http://www.petre.org.uk/pdf/Giljum\%20et\%20al_GRAMresults_petrE.pdf (accessed on 6 February 2020).

7. Chalmin, P.; Gaillochet, C. FromWaste to Resource: An Abstract of World Waste Survey 2009. Available online: http://www.veolia-environmentalservices.com/veolia/ressources/files/1/927,753,Abstract_2009_GB1.pdf (accessed on 6 February 2020).

8. Yeheyis, M.; Hewage, K.; Alam, M.S.; Eskicioglu, C.; Sadiq, R. An overview of construction and demolition waste management in Canada: A lifecycle analysis approach to sustainability. Clean Technol. Environ. Policy 2013, 15, 81-91. [CrossRef]

9. Yarime, M.; Trencher, G.; Mino, T.; Scholz, R.W.; Olsson, L.; Ness, B.; Frantzeskaki, N.; Rotmans, J. Establishing sustainability science in higher education institutions: Towards an integration of academic development, institutionalization, and stakeholder collaborations. Sustain. Sci. 2012, 7, 101-113. [CrossRef]

10. Zelenika, I.; Moreau, T.; Lane, O.; Zhao, J. Sustainability education in a botanical garden promotes environmental knowledge, attitudes and willingness to act. Environ. Educ. Res. 2018, 24, 1581-1596. [CrossRef] 
11. Álvarez, P.; Vega, P. Actitudes ambientales y conductas sostenibles. Implicaciones para la educación ambiental. Rev. Psicodidác 2009, 14, 245-260.

12. Gifford, R. The dragons of inaction: Psychological barriers that limit climate change mitigation and adaptation. Am. Psychol. 2011, 66, 290-302. [CrossRef]

13. Whitmarsh, L.; Lorenzoni, I.; O'Neill, S. Engaging the Public with Climate Change: Behaviour Change and Communication; Routledge: London, UK, 2012.

14. Gu, B.; Jiang, S.; Wang, H.; Wang, Z.; Jia, R.; Yang, J.; He, S.; Cheng, R. Characterization, quantification and management of China's municipal solid waste in spatiotemporal distributions: A review. Waste Manag. 2017, 61,67-77. [CrossRef]

15. Nie, Y.; Wu, Y.; Zhao, J.; Zhao, J.; Chen, X.; Maraseni, T.; Qian, G. Is the finer the better for municipal solid waste (MSW) classification in view of recyclable constituents? A comprehensive social, economic and environmental analysis. Waste Manag. 2018, 79, 472-480. [CrossRef] [PubMed]

16. UNESCO. Education for Sustainable Development Goals: Learning Objectives; UNESCO: Paris, France, 2018; Available online: http://unesdoc.unesco.org/images/0024/002474/247444e.pdf (accessed on 30 November 2018).

17. Tian, M.; Pu, B.; Chen, Y.; Zhu, Z. Consumer's waste classification intention in China: An extended theory of planned behavior model. Sustainability 2019, 11, 6999. [CrossRef]

18. UNESCO. Conferencia Mundial sobre la Educación Superior-2009: La nueva dinámica de la educación superior y la investigación para el cambio social y el desarrollo; UNESCO: Paris, France, 2009; Available online: http: //www.unesco.org/education/WCHE2009/comunicado_es.pdf (accessed on 6 February 2020).

19. UNESCO. UNESCO Roadmap for Implementing the Global Action Programme on Education for Sustainable Development; UNESCO: Paris, France, 2014.

20. UNESCO. Sustainable Development Goals (Online); UNESCO: Paris, France, 2015; Available online: http: //en.unesco.org/sdgs (accessed on 6 February 2020).

21. Directiva 2009/28/CE del Parlamento Europea y del Consejo del 23 de abril del 2009 relativa al fomento del uso de la energía procedente de fuentes renovables. Diario Oficial de la Unión Europea 2009, 140, $16-62$.

22. Europeo, P. Directiva 2009/33/CE del Parlamento Europea y del Consejo del 23 de abril del 2009 relativa a la promoción de vehículos de transporte por carretera limpios y energéticamente eficientes. Diario Oficial de la Unión Europea 2009, 120, 5-12.

23. Directiva 2003/66/CE de la Comisión, de 3 de julio de 2003 respecto al etiquetado energético de los frigoríficos, congeladores y aparatos combinados electrodomésticos. Diario Oficial de la Unión Europea 2003, 170, 10-14.

24. Directiva 2002/31/CE del Parlamento Europeo y del Consejo, de 19 de mayo del 2010, relativa a la eficiencia energética de los edificios. Diario Oficial de la Unión Europea 2002, 153, 13-35.

25. Directiva 2008/98/CE del Parlamento Europeo y del Consejo, de 19 de noviembre de 2008, sobre los residuos. Diario Oficial de la Unión Europea 2008, 34, 99-126.

26. BOE; Boletín Oficial del Estado; Official Spanish Gazette. Ley 22/2011 de 28 de julio. Ley de residuos y suelos contaminados [Law 22/2011 of July 28. Law on Waste and Contaminated Soils]; Agencia Estatal Boletín Oficial del Estado: Madrid, Spain, 2011.

27. Mora-William, M. Respuesta de la universidad a los problemas socio-ambientales: La ambientalización del currículo en la educación superior. Investigación en la Escuela 2007, 63, 65-76.

28. Vega, P.; Freitas, M.; Álvarez, P.; Fleuri, R. Marco teórico y metodológico de Educación Ambiental e Intercultural para un Desarrollo Sostenible. Revista Eureka Sobre Enseñanza y Divulgación de las Ciencias 2007, 4, 539-554. [CrossRef]

29. Zamora-Polo, F.; Sánchez-Martín, J. Teaching for a better world. Sustainability and sustainable development goals in the construction of a change-maker university. Sustainability 2019, 11, 4224. [CrossRef]

30. UNESCO. United Nations Decade of Education for Sustainable Development (2005-2014): International Implementation Scheme; UNESCO: Paris, France, 2004.

31. Álvarez, O.; Sureda-Negre, J.; Comas, R. El concepto "desarrollo sostenible" en los libros de texto de la Educación Secundaria Obligatoria. Rev. Electr. Inv. Innov. Educ. Socioeduc. 2012, 3, 179-197.

32. Vega, P.; Álvarez, P. Planteamiento de un marco teórico de la Educación Ambiental para un desarrollo sostenible. Revista Electrónica de Enseñanza de las Ciencias 2005, 4, 1-16.

33. Jóhannesson, I.A.; Norðdahl, K.; Óskarsdóttir, G.; Pálsdóttir, A.; Pétursdóttir, B. Curriculum analysis and education for sustainable development in Iceland. Environ. Educ. Res. 2011, 17, 375-391. [CrossRef] 
34. Martínez, G.; Maestre, J.; Naranjo, F.L. The concept of waste within the framework of sustainable development through the analysis of the secondary education curriculum. Eurasia J. Math. Sci. Technol. Educ. 2018, 14, 255-264.

35. Martínez-Borreguero, G.; Maestre-Jiménez, J.; Naranjo-Correa, F.L.; Mateos-Núñez, M. Analysis of the concept of energy in the Spanish curriculum of secondary education and baccalaureate: A sustainable perspective. Sustainability 2019, 11, 2528. [CrossRef]

36. Marco, B. La alfabetización científica. In Didáctica de las Ciencias Experimentales; Perales, F.J., Cañal, P., Eds.; Marfil: Alcoi, Spain, 2000; pp. 141-164.

37. Manassero, M.A.; Vázquez, A. Actitudes y creencias de los estudiantes relacionados con CTS. In Enseñanza de las ciencias desde la perspectiva ciencia-tecnología-sociedad. Formación científica para la ciudadanía; Narcea: Madrid, España, 2001; pp. 162-169.

38. Caamaño, A. Presencia de CTS en el currículo escolar español. In Enseñanza de las ciencias desde la perspectiva ciencia-tecnología-sociedad. Formación científica para la ciudadanía; Narcea: Madrid, España, 2001; pp. 121-133.

39. Esa, N. Environmental knowledge, attitude and practices of student teachers. Int. Res. Geogr. Environ.Educ. 2010, 19, 39-50. [CrossRef]

40. Eagly, A.H.; Chaiken, S. The Psychology of Attitudes; H.B.J. College Publishers: Orlando, FL, USA, 1993.

41. Grob, A. A structural model of environmental attitudes and behavior. J. Environ. Psychol. 1995, 15, $209-220$. [CrossRef]

42. Schultz, P.W.; Zelezny, L. Values as predictors of environmental attitudes: Evidence for consistency across 14 countries. J. Environ. Psychol. 1999, 19, 255-265. [CrossRef]

43. Stern, P.C.; Oskamp, S. Managing scarce environmental resources. In Handbook of Environmental Psychology; Stokols, D., Altman, Y.I., Eds.; Wiley and Sons: New York, NY, USA, 1991; Volumen 2, pp. 1043-1088.

44. Amérigo-Cuervo Arango, M.; García, J.; Sanchez-Nuñez, T. Actitudes y comportamiento hacia el medio ambiente natural. Salud medioambiental y bienestar emocional. Univ. Psychol. 2012, 12, 845-856. [CrossRef]

45. Larijani, M. Assessment of environmental awareness among higher primary school teachers. J. Hum. Ecol. 2010, 31, 121-124. [CrossRef]

46. Stahlberg, D.; Frey, D. Actitudes I: Estructura, medida y funciones. En Introducción a la Psicología Social, una perspectiva europea; Hewstone, M., Stroebe, W., Codol, J.P., Stephenson, G.M., Eds.; Ariel: Barcelona, España, 1993; pp. 149-170.

47. Morales, P. Medición de actitudes en psicología y educación; Universidad Pontificia de Comillas/ICAI-ICADE: Madrid, España, 2000.

48. Benayas, J. Paisaje y Educación Ambiental. Evaluación de cambios de actitud hacia el entorno. Monografías de la Secretaría de Estado para las Políticas del Agua y Medio Ambiente; MOPT: Madrid, España, 1992.

49. Stern, P.C. Toward a coherent theory of environmentally significant behavior. J. Soc. Issues 2000, 56, 407-424. [CrossRef]

50. Schultz, P.W.; Oskamp, S.; Mainieriv, T. Who recycles and when? A review of personal and situational factors. J. Environ. Psychol. 1995, 15, 105-121. [CrossRef]

51. Marcén, C.; Fernandez-Manzanal, R.; Hueto, A. ¿Se pueden modificar algunas actitudes de los adolescentes frente a las basuras? Rev. Inv. Escuela 2002, 46, 63-77.

52. Martínez-Borreguero, G.; Maestre-Jiménez, J.; Mateos-Núñez, M.; Naranjo-Correa, F.L. Knowledge analysis of the prospective secondary school teacher on a key concept in sustainability: Waste. Sustainability 2019, 11, 1173. [CrossRef]

53. Turner, G.; Tekkaya, C.; Sungur, S.; Cakiroglu, J.; Ertepinar, H.; Kaplowitz, M. Assessing pre-service teachers' environmental literacy in Turkey as a mean to develop teacher education programs. Int. J. Educ. Dev. 2009, 29, 426-436.

54. Yurttaş, G.D.; Sülün, Y. What are the most important environmental problems according to the second-grade primary school students? Procedia-Social Behav. Sci. 2010, 2, 1605-1609. [CrossRef]

55. Lazzarini, B.; Pérez-Foguet, A.; Boni, A. Key characteristics of academics promoting sustainable human development within engineering studies. J. Clean. Prod. 2018, 188, 237-252. [CrossRef]

56. Zamora-Polo, F.; Sánchez-Martín, J.; Corrales-Serrano, M.; Espejo-Antúnez, L. What do university students know about sustainable development goals? A realistic approach to the reception of this UN program amongst the youth population. Sustainability 2019, 11, 3533. [CrossRef] 
57. Martínez-Borreguero, G.; Naranjo-Correa, F.L.; Maestre-Jiménez, J. Diagnóstico de las emociones asociadas al proceso de enseñanza de la tecnología en docentes en formación. Ens. Cienc. 2017, 2017, 2755-2762.

58. Mateos, M.; Martínez, G.; Naranjo, F.L. Comparación de las emociones, actitudes y niveles de autoeficacia ante áreas STEM entre diferentes etapas educativas. Eur. J. Educ. Psychol. 2019, 13, 251-267. [CrossRef]

59. Del Estado, B.O. Real Decreto 1105/2014, del 26 de diciembre por el que se establece el currículo básico de la Educación Secundaria Obligatoria y del Bachillerato. Boletín Oficial del Estado 2015, 37, 169-546.

60. Fernández Manzanal, R.; Pérez de Heredia, A.H.; Rodríguez Barreiro, L.M.; Marcén Albero, C. ¿Qué miden las escalas de actitudes? Análisis de un ejemplo para conocer la actitud hacia los residuos urbanos. Rev. Ecosistemas 2003, 12, 1-18.

61. Damasio, A. Y el cerebro creó al hombre; Destino: Barcelona, España, 2010.

62. Fernández-Abascal, E.; Martín, M.; Domínguez, J. Procesos psicológicos; Ediciones Pirámide: Madrid, España, 2001.

63. Bandura, A. Self-Efficacy: The Exercise of Control; Macmillan: Freeman, NJ, USA, 1997.

64. Hodges, C.; Gale, J.; Meng, A. Teacher self-efficacy during the implementation of a problem-based science curriculum. Contemp. Issues Technol. Teach. Educ. 2016, 16, 434-451.

65. Abdel-Gaid, S.; Trueblood, C.R.; Shrigley, R.L. A systematic procedure for constructing a valid microcomputer attitude scale. J. Res. Sci. Teach. 1986, 23, 823-839. [CrossRef]

66. Maestre-Jiménez, J.; Martínez-Borreguero, G.; Naranjo Correa, F.L. Análisis del conocimiento de Residuos del profesorado de educación secundaria en formación. Ens. Cienc. 2017, 5665-5671.

67. Cronbach, L.J. Test "reliability": Its meaning and determination. Psychometrika 1947, 12, 1-16. [CrossRef] [PubMed]

68. Reich, J.C. Global learning as general education for the twenty-first century. Educ. Res. Rev. 2012, 7, 464-473. [CrossRef]

69. Lencucha, R. A Research-based narrative assignment for global health education. Advan. Health Sci. Educ. 2014, 19, 129-142. [CrossRef]

70. Jaén, M.; Palop, E. ¿Qué piensan y cómo dicen que actúan los alumnos y profesores de un Centro de Educación Secundaria sobre la gestión del agua, la energía y los residuos? Ens. Cienc. 2011, 29, 61-74.

71. Oğuz, D.; Çakci, I.; Kavas, S. Environmental awareness of university students in Ankara, Turkey. Afr. J. Agric. Res. 2010, 5, 2629-2636.

72. Arslan, S. The influence of environment education on critical thinking and environmental attitude. Procedia-Soc. Behav. Sci. 2012, 55, 902-909. [CrossRef]

73. Garcia, E.C.; Luansing, B. Environmental awareness among select graduating college students in Region IV-A. Laguna J. Multidisc. Res. 2016, 5, 1-10.

74. Brígido, M.; Borrachero, A.B. Relación entre autoconcepto, autoeficacia y autorregulación en ciencias de futuros maestros de Primaria. Int. J. Dev. Educ. Psychol. 2011, 1, 107-113.

75. Littledyke, M. Science education for environmental awareness: Approaches to integrating cognitive and affective domains. Environ. Educ. Res. 2008, 14, 1-17. [CrossRef]

76. Rickinson, M. Learners and Learning in Environmental: A critical review of the evidence. Environ. Educ. Res. 2001, 7, 207-320. [CrossRef]

77. Fernández-Manzanal, R.F.; Hueto, A.; Marcén, C. Qué saben los adolescentes de los residuos y qué están dispuestos a hacer para que la basura no se los trague. Reflex. Educ. Amb. 2001, 29.

78. González, A. Un modelo psicosocial de preocupación ambiental. Valores y creencias implicadas en la conducta ecológica. In Medio ambiente y participación, una perspectiva desde la psicología ambiental y el derecho; San Juan, C., Berenguer, L., Corraliza, J.A., Olaizola, E.I., Eds.; Universidad del País Vasco: Bilbao, España, 2003; pp. 55-64.

79. Aramburu, F. Medio ambiente y educación; Síntesis Educación: Madrid, España, 2000.

80. Marcén, C.; Molina, P.J. La persistencia de las opiniones de los escolares sobre el Medio Ambiente. Una particular visión retrospectiva desde 1980 a 2005; MMA: Madrid, España, 2006.

81. Kortland, J. Garbage: Dumping, burning and reusing/recycling: Students' perception of the waste issue. Int. J. Sci. Educ. 1997, 19, 65-77. [CrossRef]

82. Vilches, A.; Gil, D. Emergencia planetaria: Necesidad de un planteamiento global. Rev. Educ. Siglo XX 2007, $25,19-51$.

83. Özden, M. Environmental awareness and attitudes of student teachers: An empirical research. Int. Res. Geograph. Environ. Educ. 2008, 17, 40-55. [CrossRef] 
84. Uzzell, D.L.; Rutland, A.; Whistance, D. Questioning Values in Environmental Education. In Values and the Environment; Guerrier, Y., Alexander, N., Chase, J., O’Brien, M., Eds.; Wiley: Chichester, UK, 1995; pp. 172-182.

85. López-Rodríguez, R.; Jiménez-Aleixandre, M.P. ¿Hace el profesorado verdaderamente educación ambiental cuando cree que la hace? Análisis de algunas claves para responder esta cuestión. Innov. Educ. 2004, 14, 149-170.

86. Chrobak, R.; Prieto, R.M.; Prieto, A.B.; Gaido, L.; Rotella, A. Una aproximación a las motivaciones y actitudes del profesorado de enseñanza media de la provincia de Neuquén sobre temas de Educación Ambiental. Ens. Cienc. 2006, 5 .

87. Jaén, M. Frente a la situación de crisis ambiental actual: ¿nos hemos equivocado con la educación ambiental desarrollada en las últimas décadas? Rev. Formac. Prof. 2007, 11, 21-26.

88. Sánchez-Martín, J.; Cañada-Cañada, F.; Dávila-Acedo, M.A. Just a game? Gamifying a general science class at university: Collaborative and competitive work implications. Think. Ski. Creat. 2017, 26, 51-59. [CrossRef]

89. Martínez-Borreguero, G.; Naranjo-Correa, F.L.; Mateos-Núñez, M.; Sánchez-Martín, J. Recreational experiences for teaching basic scientific concepts in primary education: The case of density and pressure. J. Math. Sci. Technol. Educ. 2018, 14, em1616.

90. Ballantyne, R.; Fien, J.; Packer, J. Program effectiveness in facilitating intergenerational influence in environmental education: Lessons from the field. J. Environ. Educ. 2001, 32, 8-15. [CrossRef]

91. Tali-Tal, R. Community-Based environmental education-A case study of teacher-parent collaboration. Environ. Educ. Res. 2004, 10, 523-543. [CrossRef]

92. Ballantyne, R.; Connell, S.; Fien, J. Students as catalysts of environmental change: A framework for researching intergenerational influence through environmental education. Environ. Educ. Res. 1998, 4, 285-298. [CrossRef]

(C) 2020 by the authors. Licensee MDPI, Basel, Switzerland. This article is an open access article distributed under the terms and conditions of the Creative Commons Attribution (CC BY) license (http://creativecommons.org/licenses/by/4.0/). 